BIOFARM

Jurnal Ilmiah Pertanian

ISSN Print: 0216-5430; ISSN Online: 2301-6442

Vol. 15, No. 2, Oktober 2019

\title{
Pengaruh Macam Varietas dan Zat Pengatur Tumbuh Alami Terhadap Pertumbuhan Kalus Tebu (Saccharum officinarum L.) Secara In Vitro
}

\section{The Effect of Varieties and Growth Regulators Natural to Cane Growth (Saccharum officinarum L.) In Vitro}

\author{
Yuni Kartika ${ }^{1 *}$ dan Eka Adi Supriyanto ${ }^{1}$ \\ ${ }^{1}$ Program Studi Agroteknologi, Fakultas Pertanian, Universitas Pekalongan \\ *Korespondensi Penulis: Yunikartikaaunikal@gmail.com
}

\begin{abstract}
ABSTRAK
Tebu salah satu komoditas pertanian penghasil gula, akan tetapi kebutuhan benih tebu belum mencukupi. Penelitian ini bertujuan untuk mengetahui pengaruh macam varietas, zat pengatur tumbuh alami terhadap pertumbuhan kalus tebu secara in vitro dan interaksinya. Penelitian ini dilaksanakan di Laboratorium Penelitian Tanah dan Tanaman Tebu Comal Baru Kabupaten Pemalang. Penelitian ini menggunakan rancangan acak lengkap (RAL) terdiri atas 2 faktor 3 ulangan. Faktor pertama macam varietas (varietas PSJT 941, PS 881, kidang kencana) faktor kedua macam zat pengatur tumbuh (IAA, air kelapa, ekstrak tauge, ekstrak jagung). Data dianalisis dengan uji $F$ dan jika terdapat beda nyata menggunkan uji BNT 5\%. Hasil penelitian menunjukkan bahwa macam veritas berbeda sangat nyata terhadap variabel saat tumbuh tunas, tinggi planlet, jumlah tunas, jumlah daun, berbeda nyata terhadap saat tumbuh akar. Varietas terbaik adalah varietas kidang kencana. Macam zat pengatur tumbuh berbeda sangat nyata terhadap semua variabel yang diamati. Zat pengatur tumbuh terbaik adalah IAA. Interaksi macam varietas dan zat pengatur tumbuh alami berbeda nyata terhadap saat tumbuh akar dan bobot segar planlet. Interaksi terbaik pada variabel saat tumbuh akar dicapai oleh varietas kidang kencana dan IAA, untuk variabel bobot segar planlet dicapai pada varietas kidang kencana dan air kelapa.
\end{abstract}

Kata kunci : Kalus, Varietas, In vitro, ZPT alami

\section{ABSTRACT}

Sugarcane is an agricultural commodity that produces sugar, but the need for sugarcane seeds is not sufficient. This study aims to determine the effect of varieties, natural growth regulators on the growth of sugarcane callus in vitro and their interactions. This research was conducted at the Comal Baru Soil and Sugarcane Research Laboratory, Pemalang Regency. This study used a completely randomized design (CRD) consisting of 2 factors and 3 replications. The first factor was the variety of varieties (varieties PSJT 941, PS 881, kidang kencana) the second factor was the kinds of growth regulators (IAA, coconut water, bean sprouts extract, corn extract). Data were analyzed with the $F$ test and if there is a significant difference using the LSD 5\% test. The results showed that the variety of veritas was very significantly different to the variables during shoot growth, plantlet height, number of shoots, number of leaves, significantly different from the time of root growth. The best variety is the kidang kencana variety. The kinds of growth regulators differed significantly on all observed variables. The best growth regulator is IAA. The interaction of various varieties and natural growth regulators was significantly different with the time of root growth and the fresh weight of plantlets. The best interaction on the variables during root growth was achieved by kidang kencana and IAA varieties, for plantlet fresh weight variables was achieved in kidang kencana and coconut water varieties.

Keywords: Callus, In vitro, varieties, ZPT natural

\section{PENDAHULUAN}

Komoditas pertanian yang menempati posisi penting adalah Tebu (Saccharum officinarum L.), karena $70 \%$ produksi gula dunia berasal dari tebu (Khan and Khatri, 2006). Berdasarkan data produksi dan konsumsi gula nasional pada tahun 20122016 menunjukkan adanya kesenjangan yang semakin membesar dan hanya dapat dipenuhi melalui impor gula. Masalah selanjutnya adalah penggunaan varietas yang digunakan (Pusat Penelitian
Perkebunan Gula Indonesia, 2017). Pemerintah Indonesia

telah menetapkan swasembada gula nasional dengan target produksi 5,7 juta ton gula pada tahun 2014. Namun pada kenyataanya target yang telah ditetapkan ini belum dapat tercapai karena beberapa faktor, antara lain kurangnya luas areal pertanaman tebu, rendahnya produktivitas, kondisi varietas tebu yang digunakan menujukkan komposisi kemasakan tidak seimbang (Indrawanto, 2010). Pengadaan benih dalam waktu cepat, skala besar, jenis seragam dan bebas dari 
Organisme Pengganggu Tanaman (OPT) sangat sulit dipenuhi melalui teknologi perbanyakan tebu secara konvensional.

Melalui kultur in vitro dapat menghasilkan tanaman baru dalam jumlah banyak untuk penyediaan benih, sehingga biaya lebih murah. Perbanyakan tanaman secara vegetative salah satunya dengan kultur jaringan. Tanaman baru secara in vitro dengan jumlah yang tidak terbatas dapat dihasilkan dari metode kultur jaringan. (Hendrayono dan Wijayani, 1994).

Keberhasilan in vitro dipengaruhi beberapa syarat yang harus di penuhi, meliputi pemilihan eksplan sebagai dasar untuk pembentukan kalus. Zat-zat tertentu dalam media dapat mempengaruhi pembentukan kalus, untuk induksi kalus banyak menggunakan media MS. (Hendrayono dan Wijayani, 1994).

Zat pengatur tumbuh merupakan senyawa yang berperan penting dalam mengarahkan pertumbuhan sel tanaman. Penggunaan zat pengatur tumbuh tergantung pada arah pertumbuhan yang diinginkan. Sitokinin dan auksin merupakan dua golongan zat pengatur tumbuh dalam kultur jaringan yang memiliki peranan sangat penting (Gunawan, 1992). Pertumbuhan akan terhambat apabila tanpa zat pengatur tumbuh dalam media, bahkan tidak tumbuh. Penggunaan zat pengatur tumbuh yang tepat akan mempengaruhi pertumbuhan kalus dan organ-organnya (Sandra, 2010).

Zat pengatur tumbuh sintetik saat ini biasa digunakan yang harganya relatif mahal dan kadang langka ketersediaannya. Untuk mengatasi hal ini perlu digunakan zat pengatur tumbuh yang murah dan dapat diperoleh dengan mudah, namun kemampuannya sama atau lebih dari zat pengatur tumbuh sintetik dalam memacu pertumbuhan tanaman yang dapat diekstrak dari senyawa bioaktif tanaman sebagai zat pengatur tumbuh.

Air kelapa mengandung asam organik ,asam amino, purin gula, asam nukleat, alkohol, vitamin, mineral dan zat pengatur tumbuh berupa auksin 0,07 mg/l, sitokinin 5,8 $\mathrm{mg} / \mathrm{l}$ dan sedikit giberelin (Bey et al., 2006). Kalus yang diberi perlakuan ekstrak jagung (K3) dan pemberian ekstrak tauge (K4) dapat tumbuh, walaupun ekstrak jagung dan tauge merupakan salah satu sitokinin alami. Ekstrak jagung memiliki konsentrasi zat pengatur tumbuh auksin 1,67 ppm, giberelin 41,23 ppm dan sitokinin 53,94 ppm, sedangkan ekstrak tauge meskipun kandungan ekstrak tauge auksin 1,66 ppm, giberelin 39,94 ppm dan sitokinin 96,26 ppm (Ulfa, 2014). Ekstrak jagung juga mengandung vitamin yang diperlukan untuk pertumbuhan akar.

Berdasarkan uraian di atas, maka dilakukan penelitian yang bertujuan untuk mengetahui tentang pengaruh macam varietas dan zat pengatur tumbuh alami terhadap terhadap pertumbuhan kalus tebu (Saccharum officinarum L.) secara in vitro.

\section{METODE PENELITIAN}

Penelitian telah dilaksanakan di Laboratorium Penelitian Tanah dan Tanaman Tebu PT. Perkebunan Nusantara Jl. Comal Baru Ampelgading kab. Pemalang dimulai pada bulan Januari - Mei 2019.

Rancangan yang digunakan dalam penelitian ini adalah rancangan acak lengkap (RAL) dengan dua faktor yaitu macam varietas (kidang kencana, PSJT 941, PS 881) dan zat pengatur tumbuh (IAA, air kelapa, ekstrak jagung, ekstrak tauge), yang masing-masing diulang sebanyak 3 kali dengan 12 kombinasi perlakuan sehingga semuanya ada 36 unit percobaan yang masing - masing unit ada 10 tanaman sampel. Data yang diperoleh dianalisis menggunakan uji $F$. Jika antara faktor yang dicoba terdapat perbedaan nyata, maka analisis dilanjutkan uji BNT taraf $5 \%$.

Variabel yang diamati meliputi: saat tumbuh akar, saat tumbuh daun, saat tumbuh tunas, tinggi planlet, panjang akar, jumlah daun, jumlah tunas, persentase hidup planlet, bobot segar planlet, bobot kering planlet.

\section{HASIL DAN PEMBAHASAN Macam Varietas}

Hasil penelitian menunjukkan bahwa macam varietas memberikan pengaruh yang berbeda sangat nyata terhadap variabel saat tumbuh tunas, tinggi planlet, jumlah tunas, jumlah daun, berbeda nyata terhadap saat tumbuh akar. Penggunaan varietas kidang kencana (Y3) memberikan hasil terbaik terhadap semua variabel pada pertumbuhan kalus tebu secara in vitro.

$$
\text { Varietas kidang kencana (Y3) }
$$
memberikan hasil yang terbaik, hal ini disebabkan karena secara genetik varietas tebu kidang kencana memiliki sifat yang lebih baik.Varietas kidang kencana memiliki sifat perkecambahan cepat dan seragam. 
Tabel 1. Angka rata-rata dan Analisis Statistik Data Penelitian Pengaruh Macam Varietas dan Zat Pengatur Tumbuh Alami

\begin{tabular}{|c|c|c|c|c|c|}
\hline Perlakuan & $\begin{array}{l}\text { Saat tumbuh } \\
\text { akar (hst) }\end{array}$ & $\begin{array}{l}\text { Saat tumbuh } \\
\text { daun (hst) }\end{array}$ & $\begin{array}{c}\text { Saat tumbuh } \\
\text { tunas (hst) }\end{array}$ & $\begin{array}{l}\text { Tinggi planlet } \\
(\mathrm{cm})\end{array}$ & $\begin{array}{l}\text { Panjang } \\
\text { akar (cm) }\end{array}$ \\
\hline \multicolumn{6}{|l|}{ Macam Varietas } \\
\hline Y1 = PSJK 941 & $5,63 a$ & 3,58 & $4,75 b$ & $15,04 a$ & 3,81 \\
\hline Y2 = PS 881 & $5,81 b$ & 3,73 & $4,98 \mathrm{c}$ & $14,96 a$ & 3,54 \\
\hline Y3 = Kidang kencana & $5,29 b$ & 3,58 & $4,52 a$ & $16,81 b$ & 3,79 \\
\hline \multicolumn{6}{|l|}{ Macam ZPT alami } \\
\hline $\mathrm{K} 1=\mathrm{IAA}$ & $4,89 b$ & $3,33 b$ & $4,36 b$ & $17,58 b$ & $4,44 b$ \\
\hline K2 = Air kelapa & $5,50 \mathrm{~b}$ & $3,36 b$ & $4,61 b$ & $16,69 b$ & $4,33 b$ \\
\hline K3 = Ekstrak jagung & $5,83 b$ & $3,89 a$ & $4,89 a$ & $14,14 a$ & $3,11 b$ \\
\hline K4 = Ekstrak tauge & $6,08 \mathrm{a}$ & $3,94 a$ & $5,14 a$ & $14,00 \mathrm{a}$ & $2,97 a$ \\
\hline
\end{tabular}

Hal ini diperkuat dengan deskripsi varietas kidang kencana memiliki sifat pertumbuhan perkecambahan yang cepat (Pusat Penelitian Perkebunan Indonesia, 2011). Widiastuty dkk., (2000) menyatakan setiap faktor genetik dari setiap varietas menyebabkan sifat varietas yang berbeda antara varietas satu dengan varietas lainnya. Menurut Panwhar dkk., (2003) produktivitas tebu tergantung dari varietas yang berkaitan dengan karakter genetik tanaman. Varietas tebu yang unggul mempunyai sifat antara lain memiliki potensi hasil yang tinggi (Santo, 1990). Memilki sifat ukuran batang yang panjang, jumlah tunas, ruas tidak pendek, diameter batang sedang, daya berkecambah yang tinggi, memiliki sudut daun yang relatif tegak, bobot segar dan jumlah daun tidak terlalu banyak merupakan ciri-ciri suatu varietas tebu unggul yang memberikan potensi hasil tinggi (Sudarti 1994).

\section{Zat Pengatur Tumbuh Alami}

Hasil penelitian menunjukkan bahwa perlakuan macam zat pengatur tumbuh berbeda sangat nyata terhadap semua variabel yang diamati, Macam zat pengatur tumbuh IAA (K1) memberikan hasil terbaik dalam pertumbuhan kalus tebu. Hal ini disebabkan oleh kandungan auksin dalam IAA adalah 98 \% (PT. Sigma Aldrich, 2019), kandungan air kelapa menunjukkan komposisi ZPT kinetin (sitokinin) 5,8 mg/l, auksin 0,07 mg/l (Bey et al., 2006). Ekstrak jagung memiliki konsentrasi zat pengatur tumbuh auksin 1,67 ppm, giberelin 41,23 ppm dan sitokinin 53,94 ppm, sedangkan kandungan ekstrak tauge auksin 1,66 ppm, giberelin 39,94 ppm dan sitokinin 96,26 ppm (Ulfa, 2012).

Peran auksin terlihat dalam banyak proses fisiologi dalam tumbuhan, misalnya pemanjangan sel, inisiasi akar, dan pembentukan kalus. Auksin dalam kultur jaringan pada umumnya digunakan untuk menginduksi akar. Hal ini terbukti dari hasil penelitian dimana variabel saat muncul akar, dan panjang akar tertinggi dicapai oleh perlakuan macam zat pengatur tumbuh IAA.

Harjadi (2009), menyatakan bahwa proses-proses fisiologi termasuk perangsangan akar merupakan aktivitas auksin yang berkonjugasi dengan asam amino. Menurut Campbell (2002), peningkatkan permeabilitas dinding sel yang akan mempertinggi penyerapan unsur karena dilakukan pemberian auksin eksogen, auksin yang bergerak masuk ke tanaman akan memacu pembentukan sitokinin yang nantinya membantu pembentukan dan perkembangan akar.

Hasil penelitian menunjukkan pemberian air kelapa memberikan hasil terbaik terhadap bobot segar dan bobot kering planlet hal ini diduga air kelapa mengandung vitamin dan sukrose yang tinggi. Bobot segar planlet merupakan akumulasi hasil metabolisme sel terutama protein dan air, serta hasil penimbunan fotosintat yang di peroleh dari media. 
Tabel 2. Angka rata-rata dan Analisis Statistik Data Penelitian Pengaruh Macam Varietas dan Zat Pengatur Tumbuh Alami

\begin{tabular}{lccccc}
\hline \multicolumn{1}{c}{ Perlakuan } & $\begin{array}{c}\text { Jumlah } \\
\text { daun } \\
\text { (helai) }\end{array}$ & $\begin{array}{c}\text { Jumlah } \\
\text { tunas }\end{array}$ & $\begin{array}{c}\text { Presentase } \\
\text { hidup } \\
\text { planlet }\end{array}$ & $\begin{array}{c}\text { Bobot } \\
\text { segar } \\
\text { planlet } \\
\text { (g) }\end{array}$ & $\begin{array}{c}\text { Bobot } \\
\text { kering } \\
\text { planlet } \\
(\mathrm{g})\end{array}$ \\
\hline Macam Varietas & & & & & \\
Y1 = PSJK 941 & $31,06 \mathrm{a}$ & $3,81 \mathrm{a}$ & 89,58 & 1,51 & 0,17 \\
Y2 = PS 881 & $30,83 \mathrm{a}$ & $3,52 \mathrm{a}$ & 87,50 & 1,43 & 0,17 \\
Y3 = Kidang kencana & $36,92 \mathrm{~b}$ & $4,15 \mathrm{~b}$ & 88,54 & 1,56 & 0,17 \\
\hline Macam ZPT alami & & & & & \\
K1 = IAA & $40,94 \mathrm{c}$ & $4,69 \mathrm{~b}$ & $93,06 \mathrm{~b}$ & $1,65 \mathrm{~b}$ & $0,19 \mathrm{c}$ \\
K2 = Air kelapa & $34,64 \mathrm{~b}$ & $4,33 \mathrm{~b}$ & $91,67 \mathrm{~b}$ & $1,81 \mathrm{~b}$ & $0,21 \mathrm{~b}$ \\
K3 = Ekstrak jagung & $29,68 \mathrm{a}$ & $3,19 \mathrm{a}$ & $87,50 \mathrm{~b}$ & $1,28 \mathrm{a}$ & $0,15 \mathrm{a}$ \\
K4 = Ekstrak tauge & $26,49 \mathrm{a}$ & $3,08 \mathrm{a}$ & $81,94 \mathrm{a}$ & $1,26 \mathrm{a}$ & $0,14 \mathrm{a}$ \\
\hline Keterangan : Keterangan : Angka yang diikuti huruf yang sama pada kolom dan baris menunjukkan tidak berbeda nyata \\
menurut uji BNT taraf 5\%
\end{tabular}

Sukrosa akan memberikan energi. Diduga pemberian sukrosa mempengaruhi bobot segar planlet (Lisiana, 2013). Menurut Vigliar et al., (2006) kandungan air kelapa ditemukan 3 jenis gula, yakni glukosa dengan komposisi $34-45 \%$, sukrosa dari $53 \%$ sampai $18 \%$ dan fruktosa dari $12-36 \%$.

Kalus yang diberi perlakuan ekstrak jagung (K3) dan pemberian ekstrak tauge (K4) dapat tumbuh, walaupun ekstrak jagung dan tauge merupakan salah satu sitokinin alami. Ekstrak jagung memiliki konsentrasi zat pengatur tumbuh auksin 1,67 ppm, giberelin 41,23 ppm dan sitokinin 53,94 ppm, sedangkan ekstrak tauge meskipun kandungan ekstrak tauge auksin 1,66 ppm, gibberellin 39,94 ppm dan sitokinin 96,26 ppm (Ulfa, 2014). Vitamin yang diperlukan untuk pertumbuhan akar juga terdapat dalam ekstrak jagung. Menurut Macdonald (2002) vitamin pada umumnya dibutuhkan untuk pertumbuhan tanaman, khususnya untuk penelitian lanjutan yang dilakukan adalah aklimatisasi, namun planlet menunjukkan kematian. Planlet hasil kultur jaringan telah diupayakan untuk ditumbuhkan pada media tumbuh dan kondisi aklimatisasi, dengan mempertimbangkan cahaya, suhu dan kelembaban. Hasil penelitian menunjukkan bahwa planlet mengalamai stagnasi pertumbuhan kemudian terjadi kelayuan dan keguguran daun yang pada akhirnya mati, sehingga pertumbuhan benih tidak dapat diteruskan pada kondisi in vivo. Media aklimatisasi dan kondisi kelembaban merupakan penyebab kegagalan tumbuh planlet yang memicu terjadinya layu permanen pada planlet, kelembaban pada aklimatisasi mencapai 50-60 \%.

\section{Interaksi Antara Macam Varietas dan Zat Pengatur Tumbuh Alami}

Hasil penelitian menunjukkan adanya interaksi macam varietas dan ZPT alami berbeda nyata terhadap saat tumbuh akar dan bobot segar planlet. Interaksi terbaik pada variabel saat tumbuh akar dicapai oleh varietas kidang kencana dan pemberian IAA (Y3K1) yaitu 4,42 hst. Interaksi terbaik untuk variabel bobot segar planlet dicapai oleh varietas kidang kencana dan pemberian air kelapa (Y3K2) yaitu 2,02 g. 
Tabel 3. Angka rata-rata Interaksi Penelitian Pengaruh Konsentrasi dan Interval Pemberian PGPR.

Kombinasi perlakuan saat tumbuh akar (hst) bobot segar planlet (g)

\begin{tabular}{lcc}
\hline Y1K1 & $4,75 \mathrm{ab}$ & $1,70 \mathrm{~b}$ \\
Y1K2 & $5,33 \mathrm{bc}$ & $1,97 \mathrm{~cd}$ \\
Y1K3 & $6,17 \mathrm{~d}$ & $1,27 \mathrm{a}$ \\
Y1K4 & $6,25 \mathrm{de}$ & $1,12 \mathrm{a}$ \\
Y2K1 & $5,50 \mathrm{c}$ & $1,54 \mathrm{~b}$ \\
Y2K2 & $5,67 \mathrm{c}$ & $1,44 \mathrm{ab}$ \\
Y2K3 & $5,58 \mathrm{c}$ & $1,39 \mathrm{a}$ \\
Y2K4 & $6,50 \mathrm{e}$ & $1,34 \mathrm{a}$ \\
Y3K1 & $4,42 \mathrm{a}$ & $1,72 \mathrm{bc}$ \\
Y3K2 & $5,50 \mathrm{c}$ & $2,02 \mathrm{~d}$ \\
Y3K3 & $5,75 \mathrm{~cd}$ & $1,18 \mathrm{a}$ \\
Y3K4 & $5,50 \mathrm{~d}$ & $1,31 \mathrm{a}$ \\
\hline
\end{tabular}

Keterangan : Keterangan : Angka yang diikuti huruf yang sama pada kolom dan baris menunjukkan tidak berbeda nyata menurut uji BNT taraf $5 \%$

Interaksi terjadi apabila antara perlakuan macam varietas dan zat pengatur tumbuh alami saling memberikan pengaruh. Hal ini disebabkan karena adanya faktor saling mendukung antara IAA dan varietas kidang kencana. IAA memberikan ketersediaan auksin dalam jumlah yang cukup untuk kebutuhan tanaman dan didukung dengan kidang kencana yang memiliki sifat lebih baik menyerap ZPT alami tersebut. Zat pengatur tumbuh IAA mengandung $98 \%$ auksin (PT. Sigma Aldrich, 2019). Auksin yang berperan dalam pembelahan dan pemanjangan sel, selain itu juga dalam kultur jaringan juga berperan dalam inisiasi pembentukan akar.

Harjadi (2009) menyatakan bahwa proses-proses fisiologi termasuk perangsangan akar merupakan aktivitas auksin yang berkonjugasi dengan asam amino. Menurut Lakitan (1996), bahwa pembentukan dan pemanjangan akar tergantung pada auksin yang disintesis di dalam tanaman (endogen) maupun melalui pemberian dari luar (eksogen) yang berperan merangsang pembentukan dan pemanjangan akar.

Pemberian air kelapa memberikan hasil terbaik terhadap bobot segar planlet. Bobot segar planlet merupakan akumulasi air dan hasil metabolisme sel terutama protein, serta hasil penimbunan fotosintat yang di peroleh dari media. Sukrosa akan memberikan energi. Diduga pemberian sukrosa mempengaruhi bobot segar planlet. Menurut Vigliar et al. (2006), di dalam air kelapa ditemukan 3 jenis gula, yakni glukosa dengan komposisi $34-45 \%$, sukrosa dari $53 \%$ sampai $18 \%$ dan fruktosa dari $12-36 \%$.

\section{SIMPULAN}

Berdasarkan hasil penelitian dan pembahasan dapat ditarik beberapa simpulan sebagai berikut :

1. Perlakuan macam varietas berpengaruh sangat nyata terhadap variabel saat tumbuh tunas, tinggi planlet, jumlah daun, jumlah tunas, berbeda nyata terhadap saat tumbuh akar, Varietas kidang kencana (Y3) memberikan hasil terbaik pada pertumbuhan kalus tebu secara in vitro.

2. Perlakuan zat pengatur tumbuh alami berpengaruh sangat nyata terhadap semua variabel. Pemberian IAA (K1) memberikan hasil terbaik pada pertumbuhan kalus tebu secara in vitro. 
3. Interaksi antara macam varietas dan zat pengatur tumbuh alami terhadap saat tumbuh akar dan bobot segar planlet. Saat tumbuh akar terbaik pada kidang kencana dan saat IAA (Y3K1), sedangkan pada bobot segar planlet kidang kencana dan air kelapa (Y3K2).

\section{DAFTAR PUSTAKA}

Bey, Y., Syafii W. dan Sutrisno. 2006. Pengaruh pemberian Giberelin (GA3) dan Air kelapa terhadap perkecambahan bahan biji anggrek bulan (Phalaenopsis Amabilis B1) secara in vitro. Jurnal Biogenesis, 2 (2) :41-46.

Campbell, N. A. and J. B. Reece. 2002. Biology. Sixth Edition, Pearson Education. Inc.San.

Francisco.Gunawan, L. W. 1992. Teknik Kultur Jaringan. Bogor.

Harjadi. S. 2009. Zat Pengatur Tubuh. Penebar Swadaya. Jakarta.

Hendaryono, D. P. S. dan A. Wijayani. 1994. Teknik Kultur Jaringan. Kanisius. Yogyakarta.

Indrawanto, C. Purnomo, Siswanto, Syakir, M. 2010. Budidaya dan Pasca Panen Tebu. Eksa Media. Jakarta.

Khan, I A., and A Hatri. 2006. Plantegeraion Via Organgenesis or Somatic Embogenesis inSugacane: Histological Studies. Pak.J.Bot.38(3):631-636.
Lakitan, B. 1996. Dasar-dasar Fisiologi Tumbuhan. Rajawali Pers, Jakarta.

Lisiana, J.K.J.2013. Konsentrasi sucrose dan agar dialam media pelestarian in vitro ubi jalar var. Sukuh dan Ambon.

P3GI. 2017. Teknologi Bud Chip. Puslitbang, Kediri.

PT. Sigma Aldrich. 2019. 3-indoleacetid acid plant cell clture tested, crystalline. https://www. Sigmaaldrich.com. Diakses 23 juli 2019.

Pusat Penelitian Perkebunan Indonesia. 2012. Deskripsi Varietas Tanaman

Tebu.http//www/pegi.co.id/id/pro duksi varietas.diakses november 2018.

Rahmawati 2015.Kultur Jaringan Tanaman. Cara Mudah Memahami Dan Menguasai Skala Rumah Tangga. Pustaka Lentera.

Ulfa, 2014. Peran Senyawa Bioaktif Tanaman Sebagai Zat Pengatur Tumbuh Dalam Memacu Produksi Umbi Mini Kentang Solanum tuberosum L. Pada Sistem Budidaya Aeroponik. Disertasi Program Studi IImu Pertanian Pasca Sarjana. Universitas Hasanuddin. Makassar. Vasil, T.K., 1988. 
Sudarti, L. 1994. Uji Adaptasi Klon Tebu Lahan Kering (Saccharum officinarum L. ) Pada Daerah Bercurah Hujan Tinggi.Skripsi. IPB. Bogor. Hal $10-15$.

Panwhar, R.N, H.K. Keerio, M.H. Khaan, M.A. Rajpute, G.S. Unar, M.I. Mastoi, M. Chohan, A.F. Soomro, dan A.R Keerio. 2003. Relationship between Yield and Yield Contributing Traits in Sugarcane (Saccharum officinarum L.). Pakistas Journal of Science 3 (2) : 97-99.
Vigliar, R., V.L. Sdepanian, and U. Fagundes-neto. 2006. Biochemical profile of coconut water from coconut palms planted in an inland region. J. de Pediatria. 82(4): 308-312.

Widiastuty, T., S. Avivi., D. P. Restanto. 2000. Pengaruh ukuran embriozigot terhadap regenerasi beberapa klon kakao. Jurnal Natur Indonesia. Vol 13 (3): 237247. 